\title{
PRODUÇÃO DO CONHECIMENTO E RESPONSABILIDADE DO PESQUISADOR
}

\author{
Márcia de Assunção Ferreira'
}

Há quarenta anos, a pós-graduação stricto sensu na área de Enfermagem foi implantada no Brasil, com o primeiro curso de mestrado em 1972, na Escola de Enfermagem Anna Nery-UFRJ. Desde então, os programas vêm sendo instituídos nas diversas escolas e faculdades de Enfermagem do Brasil e não param de crescer, em quantidade e qualidade.

De certo, a pós-graduação, seja mestrado ou doutorado, impulsionou a pesquisa e, por consequência, a produção do conhecimento sobre o que importa ao campo da saúde e ao cuidado de enfermagem - sua ciência e arte. Muitas foram as conquistas ao longo destes quarenta anos, expressas tanto nos espaços políticos ocupados por enfermeiras nas agências de fomento e de avaliação de programas quanto no crescente processo de qualificação dos cursos para o alcance de sua excelência, nacional e internacional. As lutas e os desafios são constantes, e os ganhos têm sido evidenciados no aumento paulatino de bolsas para pesquisadores e nas conquistas de inúmeros editais para fomento das pesquisas da área.

0 crescimento da ciência da enfermagem se faz sentir nos avanços que se têm evidenciado no campo das tecnologias de cuidado em saúde, tanto nas de processo quanto nas de produto, que se atrelam à dinâmica da produção de conhecimento. Não obstante, ainda que se reconheçam tais conquistas e avanços, tem sido pauta de diversos encontros - em reuniões de avaliação da área e eventos científicos - a responsabilidade social que nos cabe, própria da prática do pesquisador, com a produção, difusão e aplicação do conhecimento. Este foi, inclusive, tema central do Seminário Nacional de Pesquisa em Enfermagem recém-realizado, em junho de 2013. ${ }^{a}$

Este tema de debate da área se baseia no entendimento de que a ciência precisa estar a serviço da sociedade, sem a qual não faz sentido a produção do conhecimento. 0 pesquisador, em especial o de enfermagem, foco deste editorial, tem o dever moral de voltar suas pesquisas para o bem-estar da sociedade, para o confor to e o cuidado à saúde humana; se assim não fosse, não seria ele, pois, pesquisador de enfermagem. Nesse ínterim, há um sentido ético no trabalho do cientista, que transcende os cuidados aplicados nos processos de desenvolvimento de um projeto de pesquisa.

Pensar na responsabilidade do pesquisador e na ética implicada na ciência e na produção do conhecimento não se restringe ao atendimento e respeito ao que se circunscreve nas resoluções que normatizam pesquisas com seres humanos, apesar de estas serem indiscutivelmente importantes. Os princípios da ética na pesquisa e na produção do conhecimento abrangem não só a concepção da ideia que norteará o estudo - que deve ser em favor da sociedade/humanidade -, seus processos constitutivos e métodos de abordagem - como se deve conduzir a pesquisa -, seus riscos e benefícios potenciais e reais -, mas também os usos que serão feitos com seus resultados, as escolhas pelos processos de difusão e a autoria dos papers a serem publicados.

A difusão do saber produzido, em apresentações nos eventos nacionais e internacionais, os quais colocam o pesquisador em contato direto com interlocutores, sejam da academia ou da prática, é um dos caminhos que propiciam a intersubjetividade necessária à crítica científica e ao balizamento sobre a propriedade da aplicação prática dos resultados dos estudos que se produzem no campo da ciência. Dialogar com os pares sobre nossas produções, ouvir-lhes as críticas e considerar outros pontos de vistas e argumentações é emergente e salutar: faz muito bem à ciência.

A publicação dos resultados de pesquisa é um importante dispositivo de difusão que amplia as possibilidades de sua aplicação, uma vez que permite a outros estudiosos consumirem, debaterem, refutarem, replicarem e aplicarem o conhecimento que está sendo produzido. Uma pesquisa não estará concluída se não tiver seus resultados publicados. Uma pesquisa encadernada, sem visitação e citação, jaz solitária e fica na história como uma obra inacabada.

A responsabilidade social e o compromisso do pesquisador com a difusão e a aplicação do conhecimento produzido são uma importante expressão da ética na pesquisa, não devendo o produtor se regozijar com seu produto e se satisfazer com o sucesso dos resultados, somente pelo alcance no plano teórico da produção. Como parte da responsabilidade social do pesquisador, a satisfação deve ser coletiva, advinda das potencialidades de sua aplicação e de sua efetiva transferência para o plano prático, no intento de que se tenha impacto científico e social com o que se produziu.

Fazer pesquisa é um ato humano e, como tal, não se desvincula da ética que nos faz ser humano: dotado de liberdade, capacidade de escolha, decisão e ação. Se escolhemos trilhar pelo campo da ciência e decidimos fazer parte do jogo político-científico deste campo, que façamos pesquisa com a responsabilidade e o compromisso que nos cabe; em fim, sejamos éticos. 


\section{PRODUCTION OF KNOWLEDGE AND RESPONSIBILITY OF THE RESEARCHER}

Márcia de Assunção Ferreira'

Forty years ago a post graduate stricto sensu in the nursing area was established in Brazil, with the first master's degree in 1972 at the School of Nursing Anna Nery-UFRJ. Since then, the programs have been instituted in several Schools and Colleges of Nursing in Brazil and keep growing in quantity and quality.

Certainly the Graduate, master's level and the doctoral boosted the research and, consequently, the production of knowledge about what matters to the field of health and nursing care - their science and art. There have been many achievements over these forty years, expressed both in political spaces occupied by nurses in the development agencies and in the evaluation programs, concerning the growing process of qualifying courses for the achievement of excellence, national and internationally. The struggles and challenges are constant and the gains have been evidenced in the gradual increase of grants to researchers and the achievements of numerous notices for promotion of research in the area.

The growth of nursing science is noticed in the advances that have been evidenced in the field of technologies in health care, both in process and in the product, which are closely linked to the dynamics of knowledge production. Nevertheless, even if we recognize these achievements and progress, it has been in the agenda of various meetings - appointments for the area evaluation and scientific events - the social responsibility that is up to us, the researcher's own practice, with the production, dissemination and application of knowledge. This was even the central theme of the National Seminar on Nursing Research recently conducted in June 2013. ${ }^{a}$

That focus debate in this area stands in the understanding that science must be in the service for the society, without it, there's no sense for the production of knowledge. The researcher, in particular in the nursing area, which is the focus of this editorial, has a moral duty to address their research for the welfare of the society, comfort and to the human health care. Meanwhile, there is a sense of ethics in the work of the scientist who transcends the care applied in the process of developing a research project.

Thinking about the responsibility of the researcher, including ethics, science and knowledge production, is not restricted to the care and respect that is limited to the resolutions that regulate human research, although these are undeniably important. The principles of ethics in research and production of knowledge permeate from conception of the idea that will guide the study - which should be in favor of society / humanity - its constitutive processes and methods of approach - how to conduct the research - their potential risks and benefits and reality - as well as the uses to be made of its results, the choices by diffusion processes and the authorship of papers to be published.

The diffusion of produced knowledge, in presentations at national and international events, which put the researcher in direct contact with interlocutors, whether at the academy or when practicing, is one of the ways that promotes intersubjectivity necessary for the scientific critical and marking on the characteristic of the practical application of research results that are produced in the field of science. Dialogue with peers about our productions, hear their criticisms and consider other viewpoints and arguments, is motivating and salutary: it does very well to science.

The publication of research results is an important broadcast device that expands the possibilities for its application, as it allows the other students to consume the knowledge being produced, debate, refute, replicate and apply. A survey is not complete if you have not published their results. A bound research, without visitation and citation, lies lonely and go down in history as an unfinished work.

Social responsibility and commitment by the researcher with the diffusion and application of knowledge produced is an important expression of the ethics of research, the producer should not settle for their product and be satisfied with the success of the results, only by the scope of the theoretical production. As part of the social responsibility of the researcher, the satisfaction must be collective, arising out the potential of its application and its effective transfer to a practical level, in an attempt of which has scientific and social impact with what was produced.

Doing research is a human act, and thus, is not out of ethics which makes us human: endowed with freedom, choice, decision and action. If we choose to walk through the field of science and decide to be part of the political-scientific game on this field, we should do the research with the responsibility and commitment that is required, after all, let's be ethical. 


\title{
LA PRODUCCIÓN DEL CONOCIMENTO Y LA RESPONSABILIDAD DEL INVESTIGADOR
}

\author{
Márcia de Assunção Ferreira'
}

Hace cuarenta años el posgrado stricto-sensu en el área de la Enfermería fue implantado en Brasil, con el primer curso de Maestría en 1972, en la Escola de Enfermagem Anna Nery / UFRJ. Desde entonces, los Programas son instituidos en diversas Escuelas y Facultades de Enfermería en Brasil y no paran de crecer, en cantidad y calidad.

Se puede decir que el posgrado, nivel de Maestría y de Doctorado, impulsó la investigación y, por consecuencia, la producción del conocimiento sobre lo que importa al campo de la salud, y al cuidado de enfermería - su ciencia y arte. Muchas fueron las conquistas a lo largo de estos cuarenta años, expresas tanto en los espacios políticos ocupados por enfermeras en las agencias de fomento y de evaluación de Programas, cuanto en el creciente proceso de calificación de los cursos para el alcance de su excelencia, nacional e internacional. Las luchas y los retos son constantes y las ganancias han sido evidenciadas en el aumento paulatino de bolsas para investigadores y en las conquistas de incontables editales para fomento de las investigaciones del área.

El crecimiento de la ciencia de la enfermería se hace sentir en los avances que se han evidenciado en el campo de las tecnologías de cuidado en salud, tanto en las de proceso cuánto en las de producto, que se conectan a la dinámica de la producción de conocimiento. No obstante, aunque se reconozcan tales conquistas y avances, ha sido pauta de diversos encuentros - en reuniones de evaluación del área y eventos científicos - la responsabilidad social que nos cabe, propia de la práctica del investigador, con la producción, difusión y aplicación del conocimiento. Este fue, inclusive, tema central del Seminario Nacional de Investigación en Enfermería, recién realizado en junio de $2013^{\text {a }}$

Este foco de debate del área se sitúa en la comprensión de que la ciencia necesita estar al servicio de la sociedad, sin la cual no tiene sentido la producción del conocimiento. El investigador, en especial el de enfermería, foco de este editorial, tiene el deber moral de volver sus investigaciones para el bienestar de la sociedad, para el confort y el cuidado a la salud humana; si así no lo fuera no sería él, pues, investigador de enfermería. En ese sentido, hay un compromiso ético en el trabajo del científico, que transciende a los cuidados aplicados en los procesos de desarrollo de un proyecto de investigación.

Pensar en la responsabilidad del investigador y en la ética implicada en la ciencia y en la producción del conocimiento no se restringe a la atención y al respeto al que se circunscribe en las resoluciones que normalizan investigaciones con seres humanos, a pesar de que estas sean indiscutiblemente importantes. Los principios de la ética en la investigación y en la producción del conocimiento recuren desde la concepción de la idea que norteará el estudio - que debe ser en favor de la sociedad/humanidad -, sus procesos constitutivos y métodos de abordaje - como se debe conducir la investigación -, sus riesgos y beneficios potenciales y reales -, como también a los usos que serán hechos con sus resultados, a las elecciones por los procesos de difusión y a la autoría de los papers publicados.

La difusión del saber producido, en presentaciones en los eventos nacionales e internacionales, los cuales colocan el investigador en contacto directo con interlocutores, sean de la academia o de la práctica, es uno de los caminos que propician la intersubjetividad necesaria a la crítica científica y al balizamiento sobre la propiedad de la aplicación práctica de los resultados de los estudios que se producen en el campo de la ciencia. Dialogar con los pares sobre nuestras producciones, oírles las críticas y considerar otros puntos de vistas y argumentaciones es emergente y saludable: hace muy bien a la ciencia.

La publicación de los resultados de la investigación es un importante dispositivo de difusión que amplía las posibilidades de su aplicación, una vez que permite que otros estudiosos consuman el conocimiento que está siendo producido, debatan, refutan, repliquen y lo apliquen. Una investigación no está concluida si no publica sus resultados. Una investigación encuadernada, sin visitación y citación, yace solitaria y queda en la historia como una obra incompleta.

La responsabilidad social y el compromiso del investigador con la difusión y aplicación del conocimiento producido es una importante expresión de la ética en la investigación, no debiendo el productor se regocijar con su producto y satisfacerse con el éxito de los resultados, solamente por el alcance en el plan teórico de la producción. Como parte de la responsabilidad social del investigador, la satisfacción debe ser colectiva, advenida de las potencialidades de su aplicación y de su efectiva transferencia para el plan práctico, en el intento de que se tenga impacto científico y social con lo que se produjo.

Hacer investigación es un acto humano, y como tal, no se desenlaza de la ética que nos hace ser humano: dotado de libertad, capacidad de elección, decisión y acción. Si escogemos seguir por el campo de la ciencia y decidimos formar parte del juego político-científico de este campo, que hagamos investigación con la responsabilidad y el compromiso que nos cabe, en fin, seamos éticos.

${ }^{a} 17^{\circ}$. Seminário Nacional de Pesquisa em Enfermagem (SENPE), realizado por la Associação Brasileira de Enfermagem (ABEn), cuyo tema central fue "El clásico y el emergente: desafíos de la producción, divulgación y utilización del conocimiento", 03 hasta 05 de junio de 2013. 
